\title{
Investigation of the frequency of iron insufficiency among infants in a population in which routine iron supplementation is implemented
}

\author{
Nisa Eda Çullas-İlarslan¹, Fatih Günay¹, Dilber Talia İleri² Atilla Halil Elhan ${ }^{3}$, \\ Mehmet Ertem², Saadet Arsan ${ }^{4}$ \\ Divisions of ${ }^{2}$ Pediatric Hematology and Oncology and ${ }^{4}$ Neonatology, ${ }^{1}$ Department of Pediatrics; ${ }^{3}$ Department of Biostatistics, \\ Ankara University Faculty of Medicine, Ankara. E-mail: md.eda@hotmail.com \\ Received: 20th July 2017, Revised: 17th August 2017, Accepted: 30th August 2017
}

SUMMARY: Çullas-İlarslan NE, Günay F, İleri DT, Elhan AH, Ertem M, Arsan $S$. Investigation of the frequency of iron insufficiency among infants in a population in which routine iron supplementation is implemented. Turk J Pediatr 2018; 60: 22-31.

Iron deficiency anemia (IDA) represents the most common cause of anemia worldwide. Because of potential irreversible neurodevelopmental impairment, its prevention during infancy is essential. We aimed to investigate the frequency of iron insufficiency among infants in a population which routine iron supplementation is implemented; and to examine related risks. A total of 501 infants, aged 9-15 months, were screened with complete blood count and serum ferritin. Infants were divided into two groups. [Group 1 (iron insufficient), [Group 1a: Iron deficiency (ID), Group 1b: IDA (IDA)], Group 2 (Iron sufficient (IS)]. Anemia was recognized in 122 (24.3\%) infants. Microcytosis was observed in $110(90.2 \%)$ of anemic infants. Group 2 accounted for $49.5 \%(\mathrm{n}=248)$ whereas $152(30.3 \%)$ and $101(20.2 \%)$ infants belonged to Groups $1 \mathrm{a}$ and $1 \mathrm{~b}$, respectively. Multiple logistic regression analysis showed that male gender $(\mathrm{OR}=1.53 ; 95 \% \mathrm{CI} 1.07$ and 2.17$)$, receiving $>500 \mathrm{ml} /$ day cow's milk $(\mathrm{OR}=2.77 ; 95 \% \mathrm{CI} 0.87$ and 8.83$)$ and incompliance to iron supplementation $(\mathrm{OR}=2.51 ; 95 \% \mathrm{CI} 1.75$ and 3.60$)$ were distinctive characteristics of Group 1 while prevalence of iron insufficiency was higher in infants consuming less formula $(\mathrm{OR}=3.10 ; 95 \% \mathrm{CI} 2.00$ and 4.80$)$. The most frequent reasons for incompliance were consideration of supplementation as unnecessary $(n=69,31.1 \%)$ and neglection $(n=59,26.6 \%)$. Our study demonstrated a high frequency of iron insufficiency among infants in a setting utilizing national iron supplementation and "incompliance" to iron as the most evident risk factor for iron insufficiency. Effective counseling of families by health care providers concerning importance of compliance to iron prophylaxis is essential for prevention of iron insufficiency. We also suggest screening of infants for ID as well as IDA in settings with high frequency of iron insufficiency.

Key words: anemia, infancy, iron deficiency, iron deficiency anemia, iron supplementation.

Anemia is defined as hemoglobin ( $\mathrm{Hb})-2 \mathrm{SD}$ below the mean $\mathrm{Hb}$ concentration adjusted for age and gender. ${ }^{1,2}$ Iron deficiency anemia (IDA) represents the most common cause of anemia worldwide. ${ }^{3,4}$ Irreversible neurodevelopmental impairment, particularly apparent in the first few years of life, is the most relevant clinical outcome of IDA which may also be observed in iron deficiency (ID). 5-9
There has been an obvious decline in the prevalence of IDA in infants in industrialized nations throughout the last decades related with increased encouragement of breastfeeding, iron fortified infant formulas and complementary food, routine screening of anemia and prophylactic iron implementation. ${ }^{4}$ The current prevalence of ID is $8 \%$ and IDA is $1-2 \%$ in toddlers in the United States of America 


$$
\text { (U.S.A). }{ }^{10,11}
$$

IDA is a challenging health problem especially for developing countries, basically related with inadequate iron-rich food consumption, lower education and limited opportunity to reach health services. ${ }^{12}$ Current prevalence of anemia in children aged 5-59 months in Turkey was reported as $30 \%$ (95\% CI 9 and 64) by WHO while regional previous data show rates of $15-60 \% .^{2,13-16}$

Despite initiation of national iron supplementation project to infants in 2004, we believe that iron insufficiency still serves as an unsolved health issue in Turkey as we observe high rates in our daily practice. As a result, we hypothesized that iron supplementation in infancy is essential but not sufficient for prevention of iron insufficiency without "compliance".

Primary aim of this study was to investigate the frequency of iron insufficiency and associated risk factors among infants in a population which routine iron supplementation is implemented. Our secondary aim was to examine reasons for incompliance.

\section{Material and Methods}

This prospective cross-sectional study was conducted in the pediatric outpatient clinic of Ankara University Children's Hospital between April-December, 2015. The study protocol was approved by the Institutional Ethics Committee of Ankara University School of Medicine (Approval number: 02-70-15; Feb 2015). Written informed consent was obtained from the parents.

\section{Selection criteria}

Infants with a history of infection in the past two weeks, leukocytosis or high serum $\mathrm{C}$-reactive protein (CRP), previous diagnosis of IDA and/or chronic disease (kidney, gastrointestinal or lung disease, congenital or acquired heart disease, neuromuscular disease, immune deficiency), prematurity ( $<37$ weeks), low birth weight $(<2,500 \mathrm{~g})$ and missing informed consent were excluded.

\section{Patient characteristics}

In accordance with the approximate age of national screening for anemia held in Turkey, we included infants between 9-15 months. A total of 662 healthy infants in this age interval were admitted to our outpatient clinic during the study period. Among these, 74 parents $(11.2 \%)$ refused to participate, 18 $(2.7 \%)$ infants with high CRP, 29 (4.4\%) with inadequate blood samples, $36(5.3 \%)$ carrying other exclusion criteria and $4(0.6 \%)$ diagnosed as beta-thalassemia minor later were excluded. Consequently, 501 (75.7\%) infants (242 girls $48.3 \%)$ with a median age of 11 (9-15) months were evaluated.

\section{Description of iron supplementation program implemented in Turkey}

Since 2004, $10 \mathrm{mg} /$ day iron supplementation is recommended for infants aged 4-12 months within the scope of a national project called "Iron-like Turkey" and screening for anemia at 9-12 months is performed by measurement of $\mathrm{Hb}$. Although families are mainly consulted by family physicians or nurses in primary health care centers (PHCC), pediatricians also prescribe iron drops to prevent missed opportunities in cases who fail to visit PHCC. Families are reminded by doctors and/or nurses concerning the continuation and correct use of iron in each follow-up visit.

Our institution advises families to continue iron supplementation until age 2 in accordance with WHO recommendations for iron supplementation for infants living in developing nations. ${ }^{17}$ Although most side effects are easily tolerated by infants, we suggest utilizing a

Table I. Reasons for Incompliance to Iron Supplementation.

\begin{tabular}{lcc}
\hline & Number (n) & Percentile (\%) \\
\hline Consideration of iron as unnecessary & 69 & 31.1 \\
Neglection & 59 & 26.6 \\
Observed side effects & 37 & 16.6 \\
Taste problem & 34 & 15.3 \\
Did not receive any recommendation of iron & 14 & 6.3 \\
Worry about possible side effects & 9 & 4.1 \\
\hline
\end{tabular}


different preparation or switching ferrous $(+2)$ to ferric iron $(+3)$ if side effects are strong. Another option is to start with small doses and gradually increase the dose each day following cessation of iron for a couple of days.

All infants included in our study were started on ferric iron $(+3)$ drops in accordance with the iron supplementation program of Turkish Ministry of Health. Iron supplementation were mostly started to infants in PHCC ( $n=467$, $93.2 \%)$ and rarely $(n=23,4.6 \%)$ in pediatric clinics.

\section{Data collection}

Parent questionnaire: Maternal risks, demographic and socioeconomical characteristics, dietary habits, iron prophylaxis status and reasons for incompliance to iron were questioned.

\section{Definitions}

Growth parameters: Length for age (LFA), weight for age (WFA), weight for length (WFL) and body mass index (BMI) standard deviation (SD) scores (Z-scores) were calculated ${ }^{18} \mathrm{Z}$ scores -2SD - 2SD were accepted as normal, $<-2 \mathrm{SD}-\geq-3 \mathrm{SD}$ as stunted/ underweight/ wasted; < -3SD as severely stunted, severely underweighted or severely wasted, $>2$ SD as overweight and $>3$ SD as obese.

Adequate red meat consumption: $\geq 3$ portions/ week, $\geq 30 \mathrm{~g} /$ portion, as adapted from Olaya's study ${ }^{19}$.

Compliance to iron: Although not defined elsewhere, we defined "compliance" to iron as $\geq 5$ times/week for $\geq 4$ months.

\section{Laboratory tests}

Blood samples for CBC (complete blood count) $(2-3 \mathrm{ml})$ and serum ferritin $(2 \mathrm{ml})$ were obtained from each patient. In order to rule out acute subclinical infection, additional blood $(2 \mathrm{ml})$ was drawn for CRP measurement, as ferritin might also elevate as an acute phase reactant. CBC analysis was established using (Coulter Counter LH780) while CRP was measured with (UniCel DxC800 Synchron) device (Beckman Coulter, U.S.A). Serum ferritin was measured using the reactant Access Ferritin-33020 (Beckman Coulter, U.S.A).

\section{Data interpretation}

Anemia was defined as $\mathrm{Hb}<11 \mathrm{~g} / \mathrm{dl}$ as recommended by WHO guidelines for 6-24 months ${ }^{2}$. Mean corpuscular volume $(\mathrm{MCV})<$ $70 \mathrm{fl}$ was considered as microcytosis. Cut-off level of ferritin was accepted as $15 \mathrm{ng} / \mathrm{ml}$ as outlined by WHO guidelines for developing countries. ${ }^{1}$ Iron deficiency was defined as low ferritin, normal $\mathrm{Hb}$ and $\mathrm{MCV}>70 \mathrm{fl}$. A child with low hemoglobin, low ferritin and MCV $<70 \mathrm{fl}$ was diagnosed as IDA. Group 1a (ID) and Group 1b (IDA) were both called "iron insufficient" (Group 1). Infants with normal $\mathrm{Hb}$ level, normal ferritin and MCV $>70 \mathrm{fl}$ were considered IS (Group 2). Groups were compared regarding associated risks.

\section{Statistical analysis}

Multiple logistic regression analysis was used to define risk factors of outcome variables (iron insufficiency, ID and IDA). Prior to logistic regression analysis, a univariate estimate was performed by means of the

Table II. Hematological Parameters of Three Groups [Group 1a (ID) and Group 1b (IDA), Group 2 (IS)].

\begin{tabular}{lccc}
\hline & ID & IDA & IS \\
\hline Hb (g/dl), mean \pm SD & $11.80 \pm 0.57$ & $10.11 \pm 0.75$ & $11.91 \pm 0.69$ \\
RBC (x 106/mm³), mean \pm SD & $4.69 \pm 0.40$ & $4.65 \pm 0.37$ & $4.73 \pm 0.36$ \\
Hct (\%), mean \pm SD & $35.62 \pm 1.84$ & $31.77 \pm 2.14$ & $35.69 \pm 2.59$ \\
MCV (fl), mean \pm SD & $75.52 \pm 3.66$ & $67.96 \pm 5.99$ & $76.78 \pm 3.54$ \\
RDW (\%), mean \pm SD & $14.73 \pm 1.44$ & $17.12 \pm 1.99$ & $14.43 \pm 3.86$ \\
Ferritin (ng/ml), median (min-max) & $9.65(3-14.8)$ & $6(2-11.4)$ & $24.3(14-68)$ \\
\hline
\end{tabular}

ID: iron deficiency, IDA: iron deficiency anemia, IS: iron sufficient, Hb: hemoglobin, Hct: hematocrit, RBC: red blood cell, MCV: mean corpuscular volume, RDW: red blood cell distribution width 
logistic regression analysis to evaluate the association of each independent variable with the outcome variables. Variables with $\mathrm{P}<0.25$ following univariate analysis were included to the multiple logistic model along with variables of known biological importance. Chi-square test or Fisher's exact test were used for categorical variables, where applicable. For two groups, Student's t-test was used for continuous variables. Differences amongst three groups for continuous variables were evaluated by Oneway analysis of variance. When $\mathrm{p}$-value from one-way ANOVA statistics was statistically significant, multiple comparison test was used to know which group differs from which others. The Bonferroni correction was applied for all possible multiple comparisons. $\mathrm{P}<0.05$ was considered statistically significant. Statistical analysis was performed using the SPSS statistical package (v.21.0).

\section{Results}

Median time of iron supplementation of the whole study group was $5.06(0-11)$ months. Side effects of iron were constipation $(n=45$, $9 \%)$, vomiting $(n=43,8.6 \%)$, diarrhea $(n=13$, $2.6 \%)$, loss of appetite $(n=5,1 \%)$, rash $(n=1$, $0.2 \%)$ and discoloration of the teeth $(n=1$, $0.2 \%)$. Compliance to iron was reported as $55.7 \%(n=279)$. The most frequent reasons for incompliance were consideration of supplementation as unnecessary or neglection whereas side effects constituted only a small portion (Table I). The median time period of iron supplementation was observed to be longer in infants who were accepted as compliant [6.26 (4-11) months].

The hematological parameters of groups are documented in Table II. $122(24.3 \%)$ infants had anemia while microcytosis was observed in $110(90.2 \%)$ of anemic infants. Group 2 accounted for $49.5 \%(n=248)$ whereas $30.3 \%$ $(n=152)$ and $20.2 \%(n=101)$ infants belonged

Table III. Comparison of Groups with Respect to Maternal Factors and Demographic Characteristics of Infants.

\begin{tabular}{|c|c|c|c|c|}
\hline & & Iron insufficient & Iron sufficient & $\mathrm{p}$ value \\
\hline Parity & $\begin{array}{l}1 \\
>1\end{array}$ & $\begin{array}{l}119(47.0) \\
134(53.0)\end{array}$ & $\begin{array}{l}126(50.8) \\
122(49.2)\end{array}$ & 0.399 \\
\hline Interpregnancy interval (years) & $\begin{array}{l}<2 \\
\geq 2\end{array}$ & $\begin{aligned} 23 & (9.1) \\
230 & (90.9)\end{aligned}$ & $\begin{array}{c}31(12.5) \\
217(87.5)\end{array}$ & 0.219 \\
\hline $\begin{array}{l}\text { Chronic disease during } \\
\text { pregnancy }\end{array}$ & $\begin{array}{l}\text { Yes } \\
\text { No }\end{array}$ & $\begin{array}{c}22(8.7) \\
231(9.3)\end{array}$ & $\begin{array}{c}27(10.9) \\
221(89.1)\end{array}$ & 0.409 \\
\hline IDA during pregnancy & $\begin{array}{l}\text { Yes } \\
\text { No }\end{array}$ & $\begin{array}{l}127(50.2) \\
126(49.8)\end{array}$ & $\begin{array}{l}105(42.3) \\
143(57.7)\end{array}$ & 0.078 \\
\hline Iron suppl. during pregnancy & $\begin{array}{l}\text { Yes } \\
\text { No }\end{array}$ & $\begin{array}{l}168(66.4) \\
85(33.6)\end{array}$ & $\begin{array}{l}174(70.2) \\
74(29.8)\end{array}$ & 0.366 \\
\hline Age (months) & $\begin{array}{l}9-11.99 \\
12-15\end{array}$ & $\begin{array}{l}131(51.8) \\
122(48.2)\end{array}$ & $\begin{array}{l}129(52.0) \\
119(48.0)\end{array}$ & 0.958 \\
\hline Gender & $\begin{array}{l}\text { Female } \\
\text { Male }\end{array}$ & $\begin{array}{l}109(43.1) \\
144(56.9)\end{array}$ & $\begin{array}{l}133(53.6) \\
115(46.4)\end{array}$ & 0.018 \\
\hline Length for age Z-score & $\begin{array}{l}<-2 \\
-2-+2 \\
>2\end{array}$ & $\begin{aligned} 23 & (9.1) \\
218 & (86.2) \\
12 & (4.7)\end{aligned}$ & $\begin{aligned} 17 & (6.9) \\
221 & (89.1) \\
10 & (4.0)\end{aligned}$ & 0.591 \\
\hline Weight for age Z-score & $\begin{array}{l}<-2 \\
-2-+2 \\
>2\end{array}$ & $\begin{aligned} 12 & (4.7) \\
236 & (93.3) \\
5 & (2.0)\end{aligned}$ & $\begin{aligned} 10 & (4.0) \\
230 & (92.8) \\
8 & (3.2)\end{aligned}$ & 0.637 \\
\hline Weight for length Z-score & $\begin{array}{l}<-2 \\
-2-+2 \\
>2\end{array}$ & $\begin{aligned} 18 & (7.1) \\
226 & (89.3) \\
9 & (3.6)\end{aligned}$ & $\begin{aligned} 10 & (4.0) \\
230 & (92.8) \\
8 & (3.2)\end{aligned}$ & 0.312 \\
\hline Body mass index Z-score & $\begin{array}{l}<-2 \\
-2-+2 \\
>2\end{array}$ & $\begin{aligned} 18 & (7.1) \\
224 & (88.6) \\
11 & (4.3)\end{aligned}$ & $\begin{array}{c}16(6.5) \\
222(89.5) \\
10(4)\end{array}$ & 0.940 \\
\hline
\end{tabular}

IDA: iron deficiency anemia, suppl: supplementation 
to Group 1a and 1b, respectively. A total of $253(50.5 \%)$ infants were iron insufficient.

Rate of multiparity and IDA during pregnancy was higher and iron supplementation in pregnancy was lower in Group 1 without statistical significance (Table III).

Age distribution of infants and growth parameters were similar in both groups. Predominance of male gender was significant in Group $1(\mathrm{p}=0.018)$ (Table III).

Duration of exclusive breastfeeding was longer $(p<0.001)$, ratio of infants still receiving breastmilk was higher $(p<0.001)$ and number of infants receiving more than half of daily feedings with formula was less $(p<0.001)$ in Group 1. Although not significant, more infants consumed $>500 \mathrm{ml} /$ day cow's milk in Group 1 $(p=0.073)$. Consumption of red meat, timing

Table IV. Comparison of Dietary Habits, Iron Prophylaxis Status and Socioeconomic Characteristics of Group 1 (Iron insufficient) and Group 2 (IS).

\begin{tabular}{|c|c|c|c|c|}
\hline & & Iron insufficient & Iron sufficient & $\mathrm{p}$ value \\
\hline Exclusive breastfeeding (months) & $\begin{array}{l}<4 \\
4.1-6 \\
>6\end{array}$ & $\begin{aligned} 56 & (22.1) \\
180 & (71.2) \\
17 & (6.7)\end{aligned}$ & $\begin{aligned} 100 & (40.3) \\
136 & (54.9) \\
12 & (4.8)\end{aligned}$ & $<0.001$ \\
\hline Infants still receiving breastmilk & $\begin{array}{l}\text { Yes } \\
\text { No }\end{array}$ & $\begin{array}{l}204(80.6) \\
49(19.4)\end{array}$ & $\begin{array}{l}164(66.1) \\
84(33.9)\end{array}$ & $<0.001$ \\
\hline $\begin{array}{l}\text { Receiving }>1 / 2 \text { of daily } \\
\text { feeding as formula }\end{array}$ & $\begin{array}{l}\text { Yes } \\
\text { No }\end{array}$ & $\begin{array}{l}37(14.6) \\
216(85.4)\end{array}$ & $\begin{array}{c}86(34.7) \\
162(65.3)\end{array}$ & $<0.001$ \\
\hline $\begin{array}{l}\text { Introduction of complementary food } \\
\text { (months) }\end{array}$ & $\begin{array}{l}<4 \\
4-5.99 \\
6 \\
>6\end{array}$ & $\begin{aligned} 29 & (11.5) \\
54 & (21.3) \\
147 & (58.1) \\
24 & (9.1)\end{aligned}$ & $\begin{aligned} 25 & (10.1) \\
56 & (22.6) \\
143 & (57.7) \\
24 & (9.7)\end{aligned}$ & 0.949 \\
\hline Adequate red meat consumption & $\begin{array}{l}\text { Yes } \\
\text { No }\end{array}$ & $\begin{array}{c}62(24.5) \\
191(75.5)\end{array}$ & $\begin{array}{l}56(22.6) \\
192(77.4)\end{array}$ & 0.612 \\
\hline Introduction of cow's milk (months) & $\begin{array}{l}<12 \\
\geq 12 / \text { not yet }\end{array}$ & $\begin{array}{l}40(15.8) \\
213(84.2)\end{array}$ & $\begin{array}{l}49(19.8) \\
199(80.2)\end{array}$ & 0.248 \\
\hline $\begin{array}{l}\text { Amount of daily received cow's milk } \\
(\mathrm{ml})\end{array}$ & $\begin{array}{l}\leq 500 / \text { not yet } \\
>500\end{array}$ & $\begin{aligned} 242 & (95.7) \\
11 & (4.3)\end{aligned}$ & $\begin{array}{c}244(98.4) \\
4(1.6)\end{array}$ & 0.073 \\
\hline Received iron recommendation & $\begin{array}{l}\text { Yes } \\
\text { No }\end{array}$ & $\begin{aligned} 241 & (95.3) \\
12 & (4.7)\end{aligned}$ & $\begin{array}{l}246(99.2) \\
2(0.8)\end{array}$ & 0.008 \\
\hline Iron dose $(\mathrm{mg} / \mathrm{kg})$ & $\begin{array}{l}<1 \\
1-2 \\
>2\end{array}$ & $\begin{array}{c}140(55.3) \\
90(35.6) \\
23(9.1)\end{array}$ & $\begin{array}{ll}127 & (51.2) \\
95 & (38.3) \\
26 & (10.5)\end{array}$ & 0.637 \\
\hline Initiation of iron (months) ${ }^{*}$ & $\begin{array}{l}4-5 \\
\geq 6\end{array}$ & $\begin{array}{l}206(86.6) \\
32(13.4)\end{array}$ & $\begin{array}{l}197(86.8) \\
30(13.2)\end{array}$ & 0.942 \\
\hline $\begin{array}{l}\text { Duration of iron supplementation } \\
\text { (months) }\end{array}$ & $\begin{array}{l}0-3.99 \\
4-7.99 \\
\geq 8\end{array}$ & $\begin{array}{c}82(32.4) \\
120(47.4) \\
51(20.2)\end{array}$ & $\begin{array}{c}48(19.4) \\
133(53.6) \\
67(27)\end{array}$ & 0.003 \\
\hline $\begin{array}{l}\text { Proper use of iron } \\
\text { ( } \geq 5 / \text { week })\end{array}$ & $\begin{array}{l}\text { Yes } \\
\text { No }\end{array}$ & $\begin{array}{l}137(54.2) \\
116(45.8)\end{array}$ & $\begin{array}{l}182(73.4) \\
66(26.6)\end{array}$ & $<0.001$ \\
\hline Compliance to iron supplement & $\begin{array}{l}\text { Yes } \\
\text { No }\end{array}$ & $\begin{array}{l}113(44.7) \\
140(55.3)\end{array}$ & $\begin{array}{l}166(66.9) \\
82(33.1)\end{array}$ & $<0.001$ \\
\hline Maternal education (years) & $\begin{array}{l}<8 \\
\geq 8\end{array}$ & $\begin{array}{ll}122 & (48.2) \\
131 & (51.8)\end{array}$ & $\begin{array}{l}107(43.1) \\
141(56.9)\end{array}$ & 0.254 \\
\hline Paternal education (years) & $\begin{array}{l}<8 \\
\geq 8\end{array}$ & $\begin{array}{c}98(38.7) \\
155(61.3)\end{array}$ & $\begin{array}{c}96(38.7) \\
152(61.3)\end{array}$ & 0.995 \\
\hline Monthly income & $\begin{array}{l}<\mathrm{MW} \\
1-1.99 \mathrm{MW} \\
\geq 2 \mathrm{MW}\end{array}$ & $\begin{aligned} & 7(3) \\
& 117(50.2) \\
& 109(46.8) \\
&\end{aligned}$ & $\begin{array}{c}5(2.2) \\
104(45.4) \\
120(52.4) \\
\end{array}$ & 0.451 \\
\hline
\end{tabular}

*(among infants whose families initiated iron supplementation), MW: minimum wage 
of introduction of solid food and cow's milk were similar between groups (Table IV).

Duration of iron supplementation was shorter $(p=0.003)$ and compliance to iron was lower $(\mathrm{p}<0.001)$ while less infants received iron recommendation $(\mathrm{p}=0.008)$ and used iron in a proper frequency $(\mathrm{p}<0.001)$ in Group 1 (Table IV).

Maternal, paternal education and monthly income were similar between two groups (Table IV).

Comparison of three groups (Group 1a, 1b and 2): $\mathrm{p}<0.0167(0.05 / 3)$ was considered as significant following Bonferroni correction. Similar results with two group comparisons were obtained (Table V). Both Group 1a and $1 \mathrm{~b}$ received iron less frequently than required $(\mathrm{p}<0.001)$, were less compliant to iron $(\mathrm{p}<0.001)$ and received less formula $(\mathrm{p}<0.001)$ in comparison with Group 2 while Group 1b accounted for other differences. In addition to two group comparisons, infants with IDA were more likely to be born from multiparous pregnancies $(\mathrm{p}=0.009)$ and less educated mothers $(\mathrm{p}=0.008)$.

Multiple logistic regression analysis model (we included one variable in case of related variables) revealed higher prevalence of iron insufficiency in male infants, in infants receiving $>500 \mathrm{ml} /$ day cow's milk and in infants who were incompliant to iron. Infants who received more formula instead of cow's milk showed less prevalence of iron insufficiency (Table VI).

\section{Discussion}

Iron deficiency anemia carries major health consequences along with social and economic issues. Main reasons for IDA among infants are increased iron requirements because of rapid growth and inadequate intake of iron from dietary supply. ${ }^{20}$

Previous studies from Turkey investigating iron insufficiency in children mostly included school-aged children, consisted of small size, offered regional data and variations existed in definitions of IDA and ID. ${ }^{13-16}$ Since 2004,

Table V. Summary of The Statistically Significant Comparison Findings Amongst Three Groups (Group 1a (ID) and Group 1b (IDA), Group 2 (IS).

\begin{tabular}{llcccc}
\hline Parameters & & ID & IDA & IS & p value \\
\hline Parity & 1 & $83(54.6)$ & $36(35.6)$ & $126(50.8)$ & 0.009 \\
& $>1$ & $69(45.4)$ & $65(64.4)^{*}$ & $122(49.2)$ & \\
Gender & Female & $72(47.4)$ & $37(36.6)$ & $133(53.6)$ & 0.015 \\
& Male & $80(52.6)$ & $64(63.4)^{* *}$ & $115(46.4)$ & \\
Exclusive breastfeeding (months) & $<4$ & $47(30.9)$ & $9(8.9)$ & $100(40.3)$ & $<0.001$ \\
& $4.1-6$ & $99(65.1)$ & $81(80.2)$ & $136(54.8)$ & \\
& $>6$ & $6(3.9)$ & $11(10.9)^{*}$ & $12(4.8)$ & \\
Infants still receiving breastmilk & Yes & $115(75.7)$ & $89(88.1)$ & $164(66.1)$ & $<0.001$ \\
& No & $37(24.3)$ & $12(11.9)^{*}$ & $84(33.9)$ & \\
Receives > 1/2 of daily & Yes & $32(21.1)$ & $5(5)$ & $86(34.7)$ & $<0.001$ \\
feeding as formula & No & $120(78.9)$ & $96(95)^{* *}$ & $162(65.3)$ & \\
Received iron recommendation & Yes & $147(96.7)$ & $94(93.1)$ & $246(99.2)$ & 0.006 \\
& No & $5(3.3)$ & $7(6.9)^{* *}$ & $2(0.8)$ & \\
Duration of iron supplementation & $0-3.99$ & $45(29.6)$ & $37(36.6)$ & $48(19.4)$ & 0.007 \\
(months) & $4-7.99$ & $78(51.3)$ & $42(41.6)$ & $133(53.6)$ & \\
& $\geq 8$ & $29(19.1)$ & $22(21.8)^{* *}$ & $67(27)$ & \\
Proper use of iron & Yes & $89(58.6)$ & $48(47.5)$ & $182(73.4)$ & $<0.001$ \\
( $\geq 5 /$ week) & No & $63(41.4)$ & $53(52.5)^{* *}$ & $66(26.6)$ & \\
Compliance to iron supplement & Yes & $74(48.7)$ & $39(38.6)$ & $166(66.9)$ & $<0.001$ \\
& No & $78(51.3)$ & $62(61.4)^{* *}$ & $82(33.1)$ & \\
Maternal education (years) & $<8$ & $62(40.8)$ & $60(59.4)$ & $107(43.1)$ & 0.008 \\
& $\geq 8$ & $90(59.2)$ & $41(40.6)^{*}$ & $141(56.9)$ & \\
\hline
\end{tabular}

ID: Iron deficiency, IDA: Iron deficiency anemia, IS: Iron sufficient,

* different from ID and IS ** different from IS 
$10 \mathrm{mg} /$ day national iron supplementation is carried out for infants aged 4-12 months. As a result, some recent studies inform lower rates of IDA. ${ }^{20,21}$ Yazici et al. ${ }^{21}$ reported childhood anemia and IDA rates as $20.8 \%$ and $6.2 \%$, respectively. Yalcin and colleagues ${ }^{22}$ carried out the most comprehensive clinical trial in Turkey investigating the prevalence of IDA in infants following national iron supplementation and included infants from three different NUTS-1 (Nomenclature of Territorial Units for Statistics) regions of Turkey. Most infants included in this study have received iron supplementation from family physicians or nurses of the PHCC. Prevalence of anemia was $10.54 \%$ in infants aged $12-15$ months, delineating efficacy of iron supplementation. Exact prevalence of neither IDA nor ID was

Table VI. Factors Related with Anemia in Accordance with Multiple Logistic Regression Analysis.

\begin{tabular}{|c|c|c|c|c|c|c|c|}
\hline & \multicolumn{3}{|c|}{ Univariate analysis } & \multicolumn{3}{|c|}{ Multivariate analysis } \\
\hline & & OR & $95 \% \mathrm{CI}$ & $\mathrm{p}$ & Adj.* OR & $95 \% \mathrm{CI}$ & $\mathrm{p}$ \\
\hline \multirow{3}{*}{$\begin{array}{l}\text { IDA during } \\
\text { pregnancy }\end{array}$} & & & & 0.078 & & & \\
\hline & Yes & 1.37 & $0.97-1.95$ & & & & \\
\hline & No & 1.00 & & & & & \\
\hline \multirow[t]{3}{*}{ Gender } & & & & 0.018 & & & 0.019 \\
\hline & Female & 1 & & & 1 & & \\
\hline & Male & 1.53 & $1.07-2.17$ & & 1.57 & $1.08-2.28$ & \\
\hline \multirow{4}{*}{$\begin{array}{l}\text { Exclusive } \\
\text { breastfeeding } \\
\text { (months) }\end{array}$} & & & & 0.001 & & & \\
\hline & $\leq 4$ & 0.42 & $0.29-0.63$ & & & & \\
\hline & $4.1-6$ & 1 & & & & & \\
\hline & $>6$ & 1.07 & $0.50-2.32$ & & & & \\
\hline \multirow{3}{*}{$\begin{array}{l}\text { Infants still } \\
\text { breastfed }\end{array}$} & & & & $<0.001$ & & & \\
\hline & Yes & 2.13 & $1.42-3.21$ & & & & \\
\hline & No & 1 & & & & & \\
\hline \multirow{3}{*}{$\begin{array}{l}\text { Receiving formula } \\
>1 / 2 \text { of daily } \\
\text { feeds }\end{array}$} & & & & $<0.001$ & & & $<0.001$ \\
\hline & Yes & 1.00 & & & 1.00 & & \\
\hline & No & 3.10 & $2.00-4.80$ & & 3.62 & $2.27-5.77$ & \\
\hline \multirow{3}{*}{$\begin{array}{l}\text { Daily cow's milk } \\
\text { consumption (ml) }\end{array}$} & & & & 0.084 & & & 0.009 \\
\hline & $\leq 500 /$ not yet & 1.00 & & & 1.00 & & \\
\hline & $>500$ & 2.77 & $0.87-8.83$ & & 5.45 & $1.52-19.57$ & \\
\hline \multirow{3}{*}{$\begin{array}{l}\text { Received iron } \\
\text { recommendation }\end{array}$} & & & & 0.018 & & & \\
\hline & Yes & 1 & & & & & \\
\hline & No & 6.12 & $1.36-27.66$ & & & & \\
\hline \multirow{3}{*}{$\begin{array}{l}\text { Compliance } \\
\text { to iron } \\
\text { supplementation }\end{array}$} & & & & $<0.001$ & & & $<0.001$ \\
\hline & Yes & 1.00 & $1.75-3.60$ & & 1.00 & $1.78-3.80$ & \\
\hline & No & 2.51 & & & 2.60 & & \\
\hline \multirow[t]{4}{*}{ Monthly income } & & & & 0.041 & & & \\
\hline & $<\mathrm{MW}$ & 1.76 & $0.79-3.92$ & & & & \\
\hline & 1-1.99 MW & 0.71 & & & & & \\
\hline & $\geq 2 \mathrm{MW}$ & 1 & $0.49-1.04$ & & & & \\
\hline
\end{tabular}

*Adj: adjusted, IDA: iron deficiency anemia, MW: minimum wage. 
represented as ferritin was not measured in all infants. Inversely, Unal and colleagues ${ }^{23}$ reported higher rates of ID $(34.8 \%)$ and IDA (36\%) in infants following national iron supplementation. This study is limited with its small size and inclusion of infants with acute infection.

It is well known that IDA represents the tip of the iceberg as prevalence of ID is higher. As both conditions are related to developmental disturbances which may be irreversible, diagnosis of both is crucial. ${ }^{5-9}$ Our measurement of both $\mathrm{CBC}$ and plasma ferritin showed iron insufficiency in half of the infants, comparable with the recent WHO report and Unal et al.'s study. ${ }^{2,23}$ On the other hand, our data conflicts with results of Yalcin et al.'s ${ }^{22}$ study. Although both studies shared similarities such as using the same cut-off values for $\mathrm{Hb}$ and ferritin, recruiting infants who received iron from PHCC and similar compliance rates of iron supplementation, we encountered a higher rate of iron insufficiency. Moreover, ours was a single-center study held in one NUTS-1 region while Yalcin et al. ${ }^{22}$ studied infants from three different NUTS-1 regions which represented lower income and higher malnutrition, therefore expected to carry a higher risk of iron insufficiency. Lower rate of iron deficiency anemia encountered by Yalcin et al. ${ }^{22}$ might be due to enrollment of infants previously diagnosed as IDA and had already received therapeutic dose of iron.

In accordance with our study, Dömellof et al. ${ }^{24}$ also reported male predominance in infantile IDA. Proposed mechanisms are sex differences in ferritin, iron metabolism, body composition and hormonal factors. ${ }^{25}$

Similar with Abdullah et al. ${ }^{26}$, we observed longer duration of breastfeeding and less formula intake in iron insufficiency. Support for breastfeeding is an effective preventive measure against iron insufficiency because of its high bioavailability. Nevertheless, iron reserves run out after the first 4-6 months of life, raising the need for extra iron intake so forth. ${ }^{25}$ Iron fortification of food and/or commercial formulas and iron supplementation are effective strategies for prevention of iron insufficiency in infants. As Turkey's policy against IDA is mainly iron supplementation, we strongly believe that it is essential for all infants to receive iron regardless of the feeding practices.

Infants should receive $30 \%$ of daily iron needs from the diet. Heme sources have higher bioavailability. A study from Colombia reported higher $\mathrm{Hb}$ in infants receiving adequate meat. ${ }^{19}$ We demonstrated inadequate red meat consumption as it takes a while for infants to receive sufficient meat. This finding also emphasizes the necessity of iron supplementation.

An exact definition of "compliance" to iron supplementation is lacking in the literature. A study from Mexico calculated adequate compliance by using the number of days the supplement was consumed and the field staff visited to administer the syrup ${ }^{27}$. We could not use this method because we questioned parents retrospectively. Because we had to take infants younger than 1 year into consideration, we accepted minimum iron use as " 4 months" when defining compliance and observed lower prevalence of iron insufficiency in compliant infants. Yalcin et al. ${ }^{22}$ found also lower prevalence of anemia in infants who were initiated iron earlier and received recommended amount of total boxes. Another study demonstrated IDA in $2 \%$ and ID in $20 \%$ of infants receiving iron while rates were $30 \%$ and $26 \%$, respectively, in infants who failed to receive prophlaxis. ${ }^{14}$ Shibukawa et al. ${ }^{12}$ found IDA prevalence as $41.5 \%$ in infants in Brazil following institution of iron prophylaxis and linked failure of their program to low adherence to iron.

We think that the main reason of iron incompliance was ineffective counseling of families by health care providers as many incompliant families considered supplementation as unnecessary or just neglected. We also believe that current use of iron must be questioned in each child visit. Another study also concluded that the more information parents received, the more they administered iron to their infants. ${ }^{28}$

Comparison of three groups revealed multiparity and less maternal education as additional risk factors of IDA. Lopez-Florez et al. ${ }^{27}$ have drawn attention to lower maternal education as a risk factor for incompliance to iron in infants. We believe that multiparity may also increase risk of IDA of infants as it's linked 
with maternal anemia. ${ }^{29}$

Multivariate logistic regression analysis reported consumption of excessive cow's milk as an additional risk factor for iron insufficiency. Studies relate this finding due to its low iron content, possible occult gastrointestinal bleedings and inhibiton of dietary iron absorption ${ }^{26,30,31}$. Health care providers should encourage families against offering excessive amount of cow's milk to their children.

There are several limitations of this study. Including infants from one NUTS-1 region is the first limitation. Secondly, we have not recorded whether the families lived in the urban or the rural areas of Ankara. Third, recording the amount of daily consumption of green vegetables and citrus fruits which increase absorption of dietary iron would be of value. Last, our definition of "compliance" to iron supplementation might not be adequate for older infants as they should have received iron longer.

Prevention of iron insufficiency is crucial to avoid irreversible neurodevelopmental disturbance. Effective counseling of families by health care providers concerning negative impacts of iron insufficiency and importance of compliance to iron prophylaxis is essential. In addition, avoidance of excessive amount of cow's milk ingestion must be suggested and each well child visit should cover evaluation of the current use of iron. We also suggest measurement of serum ferritin levels besides $\mathrm{CBC}$ to diagnose ID as well as IDA in settings with high frequency of iron insufficiency.

\section{Acknowledgements}

We thank the children and their parents for participation in our study. We are also grateful to Leyla Zümrüt Uysal (Professor of Pediatric Hematology and Oncology, Ankara University School of Medicine) and Professors of Pediatrics from Yale New Haven Children's Hospital (Eugene D. Chapiro, Brian Forsyth, John Mishel Leventhal, Carol Weitzman, and George Lister) for their contribution to our study design and Zeynep Biyıklı Gençtürk for her help in our statistical analysis.

\section{REFERENCES}

1. World Health Organization. Iron deficiency anaemia. Assessment, prevention and control. A guide for programme managers. World Health Organization, 2001. Available at: http://www.who.int/vmnis/anaemia (Accessed January 20, 2016).

2. World Health Organization. The global prevalence of anaemia in 2011. World Health Organization, 2015. Available at: http://www.who.int/vmnis/anaemia (Accessed February 15, 2016).

3. World Health Organization. Benoist B, McLean E, Egli I, Cogswell M. Worldwide prevalence of anaemia 1993-2005. Geneva: World Health Organization, 2008. Available at: http://www.who.int/vmnis/anaemia (Accessed at February 26, 2016).

4. Baker RD, Greer FR; Committee on Nutrition American Academy of Pediatrics. Diagnosis and prevention of iron deficiency and iron deficiency anemia in infants and young children (0-3 years of age). Pediatrics 2010; 126: $1040-1050$.

5. Jáuregui-Lobera I. Iron deficiency and cognitive functions. Neuropsychiatr Dis Treat 2014; 10: $2087-$ 2095.

6. Carter RC, Jacobson JL, Burden MJ, et al. Iron deficiency anemia and cognitive function in infancy. Pediatrics 2010; 126: e427-e434.

7. Doom JR, Georgieff MK. Striking while the iron is hot: Understanding the biological and neurodevelopmental effects of iron deficiency to optimize intervention in early childhood. Curr Pediatr Rep 2014; 2: 291-298.

8. Lozoff B, Smith JB, Kaciroti N, Clark KM, Guevara S, Jimenez E. Functional significance of early-life iron deficiency: outcomes at 25 years. J Pediatr 2013; 163: 1260-1266.

9. Akman M, Cebeci D, Okur V, Angin H, Abali O, Akman AC. The effects of iron deficiency on infants' developmental test performance. Acta Paediatr 2004 93: 1391-1396.

10. U.S. Preventive Services Task Force. Iron deficiency anemia in young children: screening, Sep 2015 Available at: http://www.uspreventiveservicetaskforce. org/ (Accessed February 26, 2016).

11. Dalenius K, Borland E, Smith B, Polhamus B, Grummer- Strawn L. Centers for Disease Control and Prevention. Pediatric Nutrition Surveillance 2010 Report. 2012. Available at http://www.cdc.gov/pednss/ pdfs/PedNSS_2010_Summary.pdf (Accessed October 27, 2015).

12. Shibukawa AF, Silva EM, Ichiki WA, Strufaldi MW, Puccini RF. Prophylaxis for iron deficiency anemia using ferrous sulfate among infants followed up at a primary healthcare unit in the municipality of EmbuSP (2003/2004). Rev Paul Med 2008; 126: 96-101.

13. Gür E, Yıldız I, Celkan T. Prevalence of anemia and the risk factors among school children in Istanbul. J Trop Pediatr 2005; 51: 346-50.

14. Vatandaş N, Atay G, Tarcan A, Kanra S, Özbek N. Hayatın ilk yılında demir profilaksisi ve anemi. Çocuk Sağlığı ve Hastalıkları Dergisi 2007; 50: 12-15. 
15. Kilinç M, Yüregir GT, Ekerbiçer H. Anaemia and iron-deficiency anaemia in south-east Anatolia. Eur J Haematol 2002; 69: 280-283.

16. Keskin Y, Moschonis G, Dimitriou M, et al. Prevalence of iron deficiency among school children of different socio-economic status in urban Turkey. Eur J Clin Nutr 2005; 59: 64-71.

17. World Health Organization. Guideline: Daily iron supplementation in infants and children. Geneva: World Health Organization; 2016.

18. World Health Organization. The WHO Child Growth Standards. Available at: http://www.who.int/ childgrowth/ (Accessed February 15, 2016).

19. Olaya GA, Lawson M, Fewtrell MS. Efficacy and safety of new complementary feeding guidelines with an emphasis on red meat consumption: A randomized trial in Bogota, Colombia. Am J Clin Nutr 2013; 98: 983-993.

20. Lutter CK. Iron deficiency in young children in low-income countries and new approaches for its prevention. J Nutr 2008; 138: 2523-2528.

21. Yazıcı S, Çelik T, Seyrek K. Çocukluk çağında anemi sıklığı. İzmir Dr Behçet Uz Çocuk Hastalıkları Dergisi 2012; 2: 6-9.

22. Yalçın SS, Tezel B, Yurdakök K, et al. A communitybased iron supplementation program, "Iron-Like Turkey", and the following prevalence of anemia among infants aged 12-23 months. Turk J Pediatr 2013; 55: 16-28.

23. Unal S, Bayhan T, Eskici $H$, et al. Rate of common anaemias and iron deficiency without anemia among children admitted to Antakya state hospital. Acta Medica 2014; 3: 46-50.
24. Domellof M, Lonnerdal B, Dewey KG, Cohen RJ, Rivera LL, Hernell O. Sex differences in iron status during infancy. Pediatrics 2002; 110: 545-552.

25. Chaparro CM. Setting the stage for child health and development: prevention of iron deficiency in early infancy. J Nutr 2008; 138: 2529-2533.

26. Abdullah K, Thorpe KE, Maguire JL, et al. Risk factors, practice variation and hematological outcomes of children identified with non-anemic iron deficiency following screening in primary care setting. Paediatr Child Health 2015; 20: 302-306.

27. López-Flores F, Neufeld LM, Sotres-Álvarez D, García-Guerra A, Ramakrishnan U. Compliance to micronutrient supplementation in children 3 to 24 months of age from a semi-rural community in Mexico. Salud Publica Mex 2012; 54: 470-478.

28. Sezik HA, Can H, Kurnaz MA, Tuna M, Ay Z. Use of iron supplements in children aged 1-2 years with iron deficiency anemia: A cross-sectional study. Pak J Med Sci 2015; 31: 1227-1232.

29. Nair KM, Fernandez-Rao S, Nagalla B et al. Characterisation of anaemia and associated factors among infants and pre-schoolers from rural India. Public Health Nutr 2016; 19: 861-871.

30. Ziegler EE. Consumption of cow's milk as a cause of iron deficiency in infants and toddlers. Nutr Rev 2011; 69: S37-S42.

31. Paoletti G, Bogen DL, Ritchey AK. Severe iron-deficiency anemia still an issue in toddlers. Clin Pediatr (Phila) 2014; 53: 1352-1358. 